\title{
Seedling and Germination Stages of Tomatoes (Solanum.lycopersicum) in Pakistan under Home Remedies, Packing and Transported to Other Countries with the Proper Identification of Pest and Diseases
}

\author{
Faryal Fatima $^{1}$ and Muhammad Umar Javed ${ }^{2 *}$ \\ ${ }^{1}$ Institute of Pure and Applied Biology, Bahauddin Zakariya University, Multan, Pakistan \\ ${ }^{2}$ Department of Entomology, University of Agriculture, Faisalabad, Pakistan \\ *Corresponding Author: Muhammad Umar Javed, Department of Entomology, University of Agriculture, Faisalabad, Pakistan.
}

Received: June 11, 2019; Published: August 12, 2019

DOI: 10.31080/ASAG.2019.03.0608

\begin{abstract}
Tomato (Solanum. lycopersicum OR Lycopersico. esculentum) is a great significance vegetables in the world. Because it is a relatively short-lived crop with high yields and production, it is economically attractive and growing acreage and can be grown at the larger level of the area. Tomatoes help a healthy, balanced diet [1]. They are rich in minerals, nutrients, vitamins, essential amino acids, sugar and dietary fiber. Tomatoes contain vitamins B and C, iron, potassium, folate, vitamin $\mathrm{K}$. and phosphorus. Tomato fruit is eaten fresh in salads or in sauces, soups and meat or fish dishes and with the other vegetable cooking foods. Tomato processes the production of Jam, juice and ketchup. Canned tomatoes also transported to the other city and countries [2]. Yellow tomatoes contain the higher levels of vitamin A than red tomatoes, but red tomatoes contain lycopene, an antioxidant that helps prevent carcinogens. But the more consumption of tomato also be responsible for the stone formation in the kidney or formation of kidney stone.

Keywords: Vitamins; Optimal Yield; Phases; Tomatoes Producing Countries; Yield and Outputs; Production Area; Variety; National Problem; Climate; Soil; Site Preparation; Land Preparation; Fertilization; Irrigation Tomatoes; Harvesting; Packing; Storage; Insect; Diseases; Other Causes of Crop Damage; Future Strategy
\end{abstract}

\section{Introduction}

Tomato crops are very sensitive to viruses (TMV, TYLCV) and mosaics, earlier stage transplants of crops from August to September. At that time of the year, the viral vector, especially the whitefly, was very active. The nematode problem has also become serious. The prevalence of high temperatures in Punjab limits the summer production period. Tomatoes grown in Quetta Div, KPK (Dargai area) and Katha Saghral, Katha Misral and Kotli Dakhli villages in the Khushab area of Punjab province were severely attacked by the parasitic plant "Orobanchi". Because of this problem, farmers have suffered heavy losses. Due to the early and late blight, the flowering results are rot and the bacteria are withered, and the crop is also affected., there is no local any breed is present.

\section{Climate}

Tomatoes are very sensitive to colds. In most varieties, flowering usually does not develop above $15^{\circ} \mathrm{C}$ or above $35^{\circ} \mathrm{C}$. The best range is between $21^{\circ} \mathrm{C}$ and $24^{\circ} \mathrm{C}$. When the soil temperature is below $10^{\circ} \mathrm{C}$ or exceeds $35^{\circ} \mathrm{C}$, it will not germinate. The optimal range for germination occurs between $15.5^{\circ} \mathrm{C}$ and an average soil temperature of $29^{\circ} \mathrm{C}$. In the plains, the most difficult period of tomato production is from mid-May to June, when the temperature is very high, and the monsoon season (July to August) is pests, diseases and weeds develop rapidly.

\section{Soil}

Tomatoes thrive in almost all types of soil. Fertile sandy loam is best suited for the production of early crops. Loam and sticky soils have greater water holding capacity and are more suitable for longer production seasons. Soils rich in organic matter and mineral nutrients are suitable for increasing yields. Soil with a pH of 5.5 to 7.0 is most suitable for tomato production.

\section{Site preparation}

Land preparation is necessary to grow successful crops. At least one month prior to planting the crop, rotten farm manure should be applied to 10-12 tons of land per acre to maintain proper physical and fertility conditions. It takes five to six times to prepare the seed bed. The cultivated land must be well plated and should be thoroughly leveled to evenly distribute the water. A raised bed of 1.5 meters wide should be made. 
Seedling and Germination Stages of Tomatoes (Solanum.lycopersicum) in Pakistan under Home Remedies, Packing and Transported to Other Countries with the Proper Identification of Pest and Diseases

\section{Seed rate}

An acre of nursery requires 120 to 150 grams of seed.

\section{Nursery}

If the outside weather conditions are not conducive to the growth season, the amount of open space can be increased in the plastic tunnel. Rotten farm fertilizers, a mixture of sand and soil, each of which is used as a medium for planting transplants.

\section{Material and Methods}

- $\quad$ Seedling try

- Soil prepared by myself

- $20 \%$ organic compost, $60 \%$ garden soil, $20 \%$ fine sand collected from river Ravi.

- Mix it well with each other

Statically analysis of germination of tomato seedling and germination

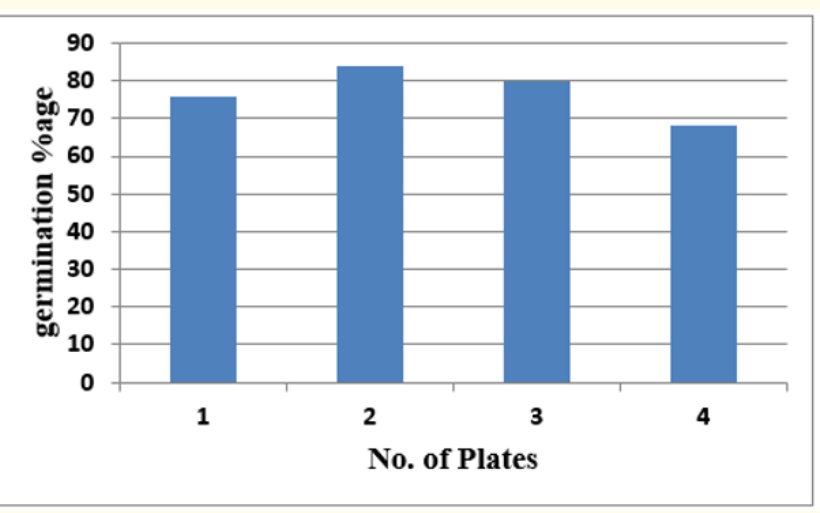

Figure 1

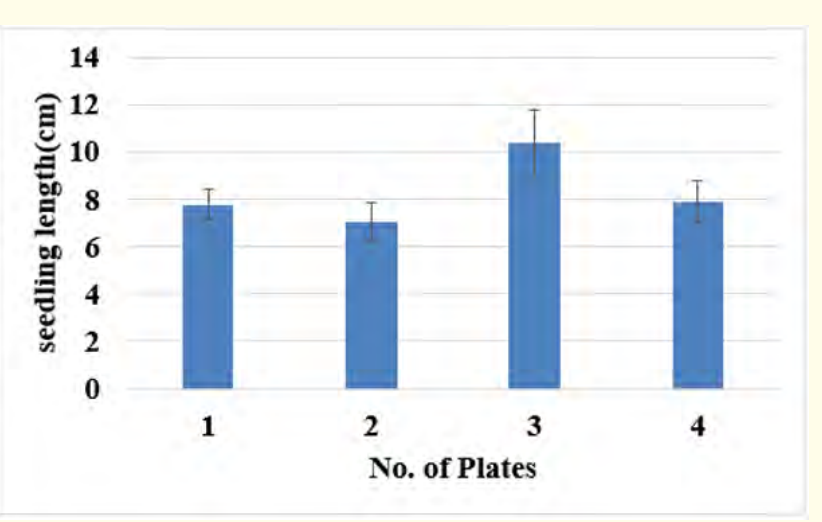

Figure 2

\begin{tabular}{|l|c|c|c|c|}
\hline \multicolumn{1}{|c|}{ Serial no } & P1 & P2 & P3 & P4 \\
\hline Germinated & 19 & 21 & 20 & 17 \\
\hline un-germinated & 6 & 4 & 5 & 8 \\
\hline Total & 25 & 25 & 25 & 25 \\
\hline \%age germination & 76 & 84 & 80 & 68 \\
\hline
\end{tabular}

Table 1

\begin{tabular}{|c|c|c|c|c|}
\hline \multirow[b]{2}{*}{ Serial no } & \multirow[b]{2}{*}{ P1 } & \multirow[b]{2}{*}{ P2 } & \multicolumn{2}{|c|}{ Seedling length $(\mathrm{cm})$} \\
\hline & & & P3 & P4 \\
\hline 1 & 5 & 11 & 3 & 6 \\
\hline 2 & 7 & 5 & 15 & 11 \\
\hline 3 & 6 & 8 & 4 & 9 \\
\hline 4 & 8 & 7 & 6 & 13 \\
\hline 5 & 11 & 10 & 7 & 5 \\
\hline 6 & 4 & 7 & 17 & 8 \\
\hline 7 & 5 & 12 & 21 & 7 \\
\hline 8 & 9 & 9 & 9 & 12 \\
\hline 9 & 7 & 13 & 12 & 14 \\
\hline 10 & 11 & 8 & 14 & 10 \\
\hline 11 & 10 & 6 & 16 & 9 \\
\hline 12 & 5 & 3 & 7 & 8 \\
\hline 13 & 5 & 2 & 18 & 6 \\
\hline 14 & 9 & 5 & 7 & 3 \\
\hline 15 & 12 & 3 & 3 & 2 \\
\hline 16 & 11 & 2 & 14 & 9 \\
\hline 17 & 7 & 9 & 3 & 2 \\
\hline Average & 7.764706 & 7.058824 & 10.35294 & 7.882353 \\
\hline $\begin{array}{l}\text { standard } \\
\text { deviation }\end{array}$ & 2.586731 & 3.418161 & 5.894289 & 3.603511 \\
\hline Square & 4.123106 & 4.123106 & 4.123106 & 4.123106 \\
\hline $\begin{array}{l}\text { Standard } \\
\text { error }\end{array}$ & 0.627374 & 0.829026 & 1.429575 & 0.87398 \\
\hline
\end{tabular}

Table 2

Equation

Rate of germination $=\frac{\text { Percentage of germinating seeds } * 100}{\text { Total numbers of seeds }}$

Percentage of Un-germinated seeds $* 100$

Rate of germination $=\frac{\text { Total numbers of seeds }}{\text { Pat }}$

Sub-optimal yield

- $\quad$ Reduce photosynthetic rate [3]

- Plant growth retardation.

- No flowers are produced. 
Seedling and Germination Stages of Tomatoes (Solanum.lycopersicum) in Pakistan under Home Remedies, Packing and Transported to Other Countries with the Proper Identification of Pest and Diseases

- $\quad$ A low percentage of fruit set [4]

- $\quad$ Slow fruit development

- $\quad$ Small fruit size.

- Low quality.

- Flower abortion.

Too much water can cause: [5]

- Insufficient oxygen in the soil.

- Plants wither.

- Root disease has become common.

- No factory development.

- No plant parts more development occur.

- $\quad$ Fruiting shrink

When arranging irrigation, the size of the root system during irrigation needs to be considered. Generally, root systems can be compared to aerial growth of plants. The roots diffuse into the soil at a rate similar to that in the air. Most tomato roots occur at soil levels between 500 and $600 \mathrm{~mm}$, even at maturity [6]. Therefore, irrometers should be used to monitor irrigation at this level. Depth, thorough irrigation is better than light and regular watering intervals. Due to the susceptibility to leaf disease [7], drip irrigation or irrigation is preferable to overhead irrigation. The amount of water used will vary depending on climatic conditions. In the colder months, tomatoes need about $25 \mathrm{~mm}$ per week, which can increase to $50 \mathrm{~mm}$ in very hot, windy and dry conditions. For irrigation purposes, tomato growth can be divided into four growth stages.

Phase 1

Establish sustainability for up to 4 weeks [8].

Seedling establishment takes place and plants begin to grow actively. Use a small amount of water.

\section{Phase 2}

Nutritional growth of the first flower and fruit development. The amount of water used is doubled compared to the previous stage [9].

\section{Phase 3}

Fruit growth is highest. The amount of water used at this stage is highest during the life of the crop [10].

\section{Phase 4}

High load on mature and harvested plants. Water consumption begins to decrease [11].

\section{Results}

Production of Tomato Plants and their seedling procedure.

\begin{tabular}{|c|c|c|}
\hline Date & Seed Response & Results \\
\hline 27-Feb-19 & No Response & No Response \\
\hline 28-Feb-19 & No Response & No Response \\
\hline 1-March-19 & No Response & No Response \\
\hline 2-March-19 & No Response & Little emergence \\
\hline 3-March-19 & Response & Little emergence \\
\hline 4 -March-19 & Small spouting & Little emergence \\
\hline 5-March-19 & Observe data $0.5 \mathrm{~mm}$ & $\begin{array}{l}\text { Minimum cocktail } \\
\text { size of Plant }\end{array}$ \\
\hline 6-March-19 & Observe data $0.6 \mathrm{~mm}$ & cocktail size of Plant \\
\hline 7-March-19 & Observe data $0.9 \mathrm{~mm}$ & cocktail size of Plant \\
\hline 8-March-19 & Observe data $1.1 \mathrm{~mm}$ & cocktail size of Plant \\
\hline 9-March-19 & Observe data $1.4 \mathrm{~mm}$ & cocktail size of Plant \\
\hline 10-March-19 & Observe data $1.6 \mathrm{~mm}$ & cocktail size of Plant \\
\hline 11-March-19 & Observe data $1.9 \mathrm{~mm}$ & cocktail size of Plant \\
\hline 12-March-19 & Observe data $2.2 \mathrm{~mm}$ & $\begin{array}{l}\text { Average cocktail size } \\
\text { of Plant }\end{array}$ \\
\hline 13-March-19 & Observe data $2.5 \mathrm{~mm}$ & $\begin{array}{l}\text { Average cocktail size } \\
\text { of Plant }\end{array}$ \\
\hline 14-March-19 & Observe data $2.9 \mathrm{~mm}$ & $\begin{array}{l}\text { Average cocktail size } \\
\text { of Plant }\end{array}$ \\
\hline 15-March-19 & Observe data 3-5 mm & $\begin{array}{l}\text { Average cocktail size } \\
\text { of Plant }\end{array}$ \\
\hline 16-March-19 & Observe data 5-8 mm & $\begin{array}{l}\text { Average cocktail size } \\
\text { of Plant }\end{array}$ \\
\hline 17-March-19 & Observe data $9-18 \mathrm{~mm}$ & $\begin{array}{l}\text { Average cocktail size } \\
\text { of Plant }\end{array}$ \\
\hline 18-March-19 & Observe data $19-25 \mathrm{~mm}$ & $\begin{array}{l}\text { Large cocktail size of } \\
\text { Plant }\end{array}$ \\
\hline 19-March-19 & Observe data $26-30 \mathrm{~mm}$ & $\begin{array}{l}\text { Large cocktail size of } \\
\text { Plant }\end{array}$ \\
\hline 20-March-19 & Observe data $25-29 \mathrm{~mm}$ & $\begin{array}{l}\text { Maximum cocktail } \\
\text { size of Plant }\end{array}$ \\
\hline 21-March-19 & Observe data $35-40$ & $\begin{array}{l}\text { Minimum medium } \\
\text { size of plant }\end{array}$ \\
\hline 22-March-19 & Observe data $41-43 \mathrm{~mm}$ & medium size of plant \\
\hline 23-March-19 & Observe data $43-48 \mathrm{~mm}$ & medium size of plant \\
\hline 24-March-19 & Observe data $48-52 \mathrm{~mm}$ & medium size of plant \\
\hline 25-March-19 & Observe data $52-55 \mathrm{~mm}$ & medium size of plant \\
\hline 26-March-19 & Observe data $55-57 \mathrm{~mm}$ & medium size of plant \\
\hline 27-March-19 & Observe data $57-59 \mathrm{~mm}$ & $\begin{array}{l}\text { Average medium size } \\
\text { of plant }\end{array}$ \\
\hline 28-March-19 & Observe data $60-62 \mathrm{~mm}$ & $\begin{array}{l}\text { Average medium size } \\
\text { of plant }\end{array}$ \\
\hline 29-March-19 & Observe data $62-63 \mathrm{~mm}$ & $\begin{array}{l}\text { Average medium size } \\
\text { of plant }\end{array}$ \\
\hline 30-March-19 & Observe data $65-68 \mathrm{~mm}$ & $\begin{array}{l}\text { Large medium size of } \\
\text { plant }\end{array}$ \\
\hline 31-March-19 & Observe data $68-71 \mathrm{~mm}$ & $\begin{array}{l}\text { Maximum large size } \\
\text { of plant }\end{array}$ \\
\hline 1-April-19 & Observe data $71-73 \mathrm{~mm}$ & $\begin{array}{l}\text { Maximum medium } \\
\text { size of Plant }\end{array}$ \\
\hline
\end{tabular}


Seedling and Germination Stages of Tomatoes (Solanum.lycopersicum) in Pakistan under Home Remedies, Packing and Transported to Other Countries with the Proper Identification of Pest and Diseases

\begin{tabular}{|c|c|c|}
\hline 2-April-19 & Observe data $73-75 \mathrm{~mm}$ & $\begin{array}{l}\text { Minimum large size } \\
\text { of plant }\end{array}$ \\
\hline 3-April-19 & Observe data $75-77 \mathrm{~mm}$ & Large size of Plant \\
\hline 4-April-19 & Observe data $77-79 \mathrm{~mm}$ & Large size of Plant \\
\hline 5-April-19 & Observe data79-81mm & Large size of Plant \\
\hline 6-April-19 & Observe data $81-82 \mathrm{~mm}$ & Large Size of Plant \\
\hline 7-April-19 & Observe data $82-83 \mathrm{~mm}$ & $\begin{array}{l}\text { Maximum Large size } \\
\text { of Plant }\end{array}$ \\
\hline 8-April-19 & Observe data $83-85 \mathrm{~mm}$ & $\begin{array}{l}\text { Minimum Extra large } \\
\text { size of plant }\end{array}$ \\
\hline $\begin{array}{l}\text { 9-April-19 } \\
\text { 10-April-19 }\end{array}$ & Observe data $86 \mathrm{~mm}$ & $\begin{array}{l}\text { Extra large size of } \\
\text { plant }\end{array}$ \\
\hline 11-April-19 & Observe data $87 \mathrm{~mm}$ & $\begin{array}{l}\text { Average Extra large } \\
\text { size of plant }\end{array}$ \\
\hline 12-April-19 & Observe data $88 \mathrm{~mm}$ & $\begin{array}{l}\text { Average Extra large } \\
\text { size of plant }\end{array}$ \\
\hline 13-April-19 & Observe data $89 \mathrm{~mm}$ & $\begin{array}{l}\text { Average Extra large } \\
\text { size of plant }\end{array}$ \\
\hline 14-April-19 & Observe data $90 \mathrm{~mm}$ & $\begin{array}{l}\text { Average Extra large } \\
\text { size of plant }\end{array}$ \\
\hline 15-April-19 & Observe data $91 \mathrm{~mm}$ & $\begin{array}{l}\text { Average Extra large } \\
\text { size of plant }\end{array}$ \\
\hline 16-April-19 & Observe data $92 \mathrm{~mm}$ & $\begin{array}{l}\text { Average Extra large } \\
\text { size of plant }\end{array}$ \\
\hline 17-April-19 & Observe data $93 \mathrm{~mm}$ & $\begin{array}{l}\text { Average Extra large } \\
\text { size of plant }\end{array}$ \\
\hline 18-April-19 & Observe data $94 \mathrm{~mm}$ & $\begin{array}{l}\text { Maximum Extra } \\
\text { Large size of Plant }\end{array}$ \\
\hline 19-April-19 & Observe data $95 \mathrm{~mm}$ & $\begin{array}{l}\text { Maximum Extra } \\
\text { Large size of Plant }\end{array}$ \\
\hline 20-April-19 & Observe data $96 \mathrm{~mm}$ & XXL size of plant \\
\hline 21-April-19 & Observe data $97 \mathrm{~mm}$ & XXL size of plant \\
\hline 22-April-19 & Observe data $98 \mathrm{~mm}$ & $\begin{array}{l}\text { XXL size of plant } \\
\text { fruiting emergence }\end{array}$ \\
\hline 23-April-19 & Observe data $99 \mathrm{~mm}$ & $\begin{array}{l}\text { XXL size of plant plant } \\
\text { fruiting emergence }\end{array}$ \\
\hline 24-April-19 & Observe data $100 \mathrm{~mm}$ & $\begin{array}{l}\text { XXL size of plant plant } \\
\text { fruiting emergence }\end{array}$ \\
\hline 25-April-19 & Observe data $101 \mathrm{~mm}$ & $\begin{array}{l}\text { XXL size of plant plant } \\
\text { fruiting emergence }\end{array}$ \\
\hline 26-April-19 & Observe data $102 \mathrm{~mm}$ & $\begin{array}{l}\text { XXL size of plant plant } \\
\text { fruiting emergence }\end{array}$ \\
\hline 27-April-19 & Observe data $103 \mathrm{~mm}$ & $\begin{array}{l}\text { XXL size of plant plant } \\
\text { fruiting emergence }\end{array}$ \\
\hline 28-April-19 & Observe data $104 \mathrm{~mm}$ & $\begin{array}{l}\text { XXL size of plant plant } \\
\text { fruiting emergence }\end{array}$ \\
\hline 29-April-19 & Observe data $105 \mathrm{~mm}$ & $\begin{array}{l}\text { XXL size of plant plant } \\
\text { fruiting emergence }\end{array}$ \\
\hline 30-April-19 & Observe data $106 \mathrm{~mm}$ & $\begin{array}{l}\text { XXL size of plant plant } \\
\text { fruiting emergence }\end{array}$ \\
\hline 1-May-19 & Observe data107 mm & $\begin{array}{l}\text { XXL size of plant plant } \\
\text { fruiting emergence }\end{array}$ \\
\hline 2-May-19 & Observe data $108 \mathrm{~mm}$ & $\begin{array}{l}\text { XXL size of plant plant } \\
\text { fruiting emergence }\end{array}$ \\
\hline
\end{tabular}

\begin{tabular}{|l|l|l|}
\hline 3-May-19 & Observe data 109mm & $\begin{array}{l}\text { XXL size of plant plant } \\
\text { fruiting emergence }\end{array}$ \\
\hline 4-May-19 & $\begin{array}{l}\text { Observe data 110- } \\
116 \mathrm{~mm}\end{array}$ & $\begin{array}{l}\text { XXL size of plant plant } \\
\text { fruiting emergence }\end{array}$ \\
\hline 5-May-19 & $\begin{array}{l}\text { Observe data120- } \\
122 \mathrm{~mm}\end{array}$ & $\begin{array}{l}\text { XXL size of plant plant } \\
\text { fruiting emergence }\end{array}$ \\
\hline 6-May-19 & Observe data......... & $\begin{array}{l}\text { XXL size of plant plant } \\
\text { fruiting emergence }\end{array}$ \\
\hline 7-May-19 & Observe data......... & $\begin{array}{l}\text { XXL size of plant plant } \\
\text { fruiting emergence }\end{array}$ \\
\hline 8-May-19 & Observe data......... & $\begin{array}{l}\text { XXL size of plant plant } \\
\text { fruiting emergence }\end{array}$ \\
\hline 9-May-19 & Observe data......... & $\begin{array}{l}\text { XXL size of plant plant } \\
\text { fruiting emergence }\end{array}$ \\
\hline
\end{tabular}

Table 3

\title{
Discussion
}

Insect [14]

All stinging and sucking insects, such as whiteflies, thrips and mites, cause physical damage only when they occur in large numbers. However, they may spread the virus, which will cause more damage. These insects may come from outside your field and may cause the entire crop to become infected. In addition, leaves damaged by insects become more susceptible to fungal and bacterial diseases. Closed glass, plastic sheets or mosquito nets, or a combination of these, protect crops from insect attacks and viruses.

White fly

\author{
Scientific name: Aleyrodidae \\ Order: Hemiptera \\ Class: Insecta
}

White fly (Bemisia tabaci) Adult fly white, 1-2 mm long. Like a larva, it eats on the leaves and juice. When the leaves of the plants turn over, a whole group of whiteflies may fly. They lay eggs under the leaves. Eggs hatch after about 1 week. After 2 to 4 weeks, the larvae form sputum, and metamorphosis takes about a week. Whitefly is especially problematic in the dry season. Once the rainy season begins, they will disappear. Some measures to combat whitefly: Encourage the presence of natural enemies of whiteflies by planting shrubs or other plants (plants) between crop rows or along the route between the borders. Use resistant varieties (hairy leaves make it difficult for whiteflies to lay eggs). Spray kerosene and soap solution to control whiefly.

\section{Aphids}

\section{Scientific name: Aphidoidea}

Order: Hemiptera

Class: Insecta

Higher classification: Sternorrhyncha

Family: Aphidae 
Aphids are soft, oblong-shaped insects that are about $2.5 \mathrm{~mm}$ long. Aphids with wings and no wings. Direct damage occurs when they attack crops in large numbers, especially the youngest leaves and stems. In addition to causing direct damage, mites also spread a variety of viruses. Measures to control

- Remove old crop residues before planting new crops.

- Intercropping with other crops.

- Use appropriate amount of nitrogen fertilizer.

- Spray a solution of soap, bovine urine or extract (Azadirachta indica)

- Cover the ground with a gray plastic sheet and repel the mites by reflecting sunlight.

\section{Thrips [15]}

Scientific name: Thysanoptera

Order: Thysanoptera;

The thrips are very small insects, only 0.5 to $2 \mathrm{~mm}$ long. You must look at them carefully. They usually have wings. The thrips lay their eggs on the leaves. Larvae appear about 10 days later. Larvae and adult sucking sap, causing silver.

\section{Spots on the leaves}

Adult also leave their excrement on the leaves; these are small black spots.

Measures to control thrips:

- Cover the floor with a plastic sheet to prevent the thrips from entering the soil for the sputum stage.

- The plow is so good that the puppet is brought to the surface to dry and die.

- Remove crop residues.

- Spray the plants with soap or azadirachtin extract (Azadirachta indica).

- This does not affect the cockroaches in the soil, so it is necessary to repeat the spraying regularly to kill the adults on the ground.

\section{Butterflies and moths (Lepidoptera) [16]}

Butterflies and moths are common pests in tomato crops. They place green or brown eggs on young leaves, flowers and fruits. Hatched larvae (caterpillars) feed on leaves, flowers, fruits and even roots. At feeding, the caterpillars increase in size and pass through many larval stages. Eventually they form strontium/Cocoon in the soil. A few weeks later, these hatching and adult butterflies flew out and spread out. Measures to control caterpillars:

- Remove weeds regularly.

- Plow a month before sowing or transplanting.

- Remove and destroy infected fruits.

- Use rotation.

- Regularly check for the presence of eggs and take measures to control the larvae Use light traps that attract moths at night to prevent them from laying eggs on plants. Apply wood ash, wood chips or shavings and/or calcium to the seedbed.

\section{Leafhoppers (Cicadellidae: Empoasca fabae) [17]}

The most common tomato pest is the potato leafhopper. Leafhoppers are between 2 and 30 millimeters in length and walk laterally if they are disturbed. They place green banana-shaped eggs under the leaves. They feed on plant juices. In the place where they sucked, the color of the leaves became lighter. If the damage is severe, the entire leaf becomes light. Measures to control leafhoppers:

- If possible, plant in the rainy season.

- Use resistant varieties (such as hairy leaves make it difficult to lay eggs).

- The best time to spray with Azadirachta indica or other locally used insecticides is in the first month of plant height of about $10 \mathrm{~cm}$, as female spider mites lay eggs at this time.

\section{Mites (Tetranychus spp) [18]}

Mites are spider-like insects. They are less than $1 \mathrm{~mm}$ and are usually yellow, red or orange. They placed the eggs under the leaves. Larvae and adults draw juice from the leaves. Leaves and stems turn yellow and dry. Mites can make a thin line of ventilation nets (fleece), similar to the thin lines of a spider. They cause the most damage during the dry season. Measures to control

- If possible, plant in the rainy season.

- Stimulate the presence of predators by means of intercropping or planting near roadsides, shrubs and other vegetation.

- Spray with soap or kerosene soap solution

\section{Diseases}

Tomato plants are sensitive to several fungi, bacteria and viruses. Fungi and bacteria cause foliar (leaf), fruit, stem or root disease. Viral infections often result in dwarf growth and reduced yield. Damage caused by disease can lead to a large reduction in farmers' production. Some of the diseases common in tomatoes are discussed below.

\section{Bacterial wilt (Ralstonia solanacearum) [19]}

This bacterium is especially common in humid tropical lowlands and is relatively hot. It causes bacterial wilt, a disease transmitted by the soil. The initial symptoms of infected plants were that the terminal leaves withered, suddenly and permanently withered after 2-3 days, but did not turn yellow. Adventitious roots may develop on the main stem. The vascular system in the stem of the infected plant is light brown in the lateral or longitudinal portion; it turns dark brown at the end of the infection. When the plant is completely withered, the marrow and cortex near the soil line will also turn brown. When the stem of the infected plant is suspended in water, the white milky acterial stream will seep out of the woody portion. Bacteria survive in the soil and enter the roots of the seedlings. 
A wound made by transplanting, cultivating, insects or certain nematodes. Bacteria spread through infected plants that irrigate water, soil moves or moves the following measures will help control bacterial wilt:

- Use resistant/resistant varieties.

- Avoid infected fields.

- Do not grow the Solanceae plant for at least 7 years once the soil is infected. Rotate with cereal crops

- Do not damage the roots or leaves, so be careful during the transplant and trim as little as possible.

\section{Cucumber mosaic virus [20]}

CMV causes tomato plants to develop slowly. Leaves may have mild green spots or more lace symptoms, with the leaves being greatly reduced. The fruit is small and often deformed. CMV is transmitted by different aphid species.

Aphids usually introduce viruses into weeds or tomato crops adjacent to crops. Control vectors are important to prevent CMV epidemics:

- Plant resistant varieties.

- Because CMV has a wide range of hosts, it is necessary to eliminate weeds and ornamental plants that contain viruses

- Remove and destroy infected individual plants as this helps limit the spread of the virus in the field.

Tomato yellow leaf curl virus [21]

TYLCV is available all over the world. Infected plants are erect and stunted. The leaves are yellow and curl up or down. If the plant is infected in the nursery, the entire yield can be destroyed. Whitefly transmits TYLCV.

Common control measures:

- Use tolerant varieties.

- Use reflective plastic coverings

- Protect the seedlings with nets in the nursery

- Control insect vectors

\section{Early blight (Alternaria solani) [22]}

This fungus is found everywhere and is most effective in humid and hot climates. It spreads through seeds, wind, rain and the remains of infected plants. Damaged plants are more susceptible to this fungus. Round brown spots (with concentric rings) appear on the leaves, up to $1.5 \mathrm{~cm}$ in diameter. Sometimes small pieces can be found on the stems or leaves, causing the leaves to turn yellow and wither. Flowers and small fruits fall off. Main control measures:

- Use tolerant varieties.

- Remove and burn damaged plant parts.

- thoroughly remove weeds regularly.

- Use pathogen free seeds.

- Take a rotation
- Do not plant seedlings near older plants.

- Use effective fungicide

\section{Late blight (Phytophthora infestans) [23]}

This fungus can be found in all parts of the world, but is more common in the cool, humid environment of highlands or lowlands. Fungi are usually transmitted through crop remains. A dark, watery mark with yellow spots inside can be seen on the leaves. Sometimes the mark spreads inward from the edge of the leaf, sometimes the spot spreads out from the center of the leaf. Below the leaves, the spots are white. Stems and fruits are also affected. The fruit turns into brown spots and the leaves wither. Early signs of late blight can be seen early in the growing season. Measures to prevent late blight:

- Use tolerant varieties

- Thoroughly remove weeds regularly.

- Remove and incinerate affected plants and plant debris.

- Do not plant seedlings near older plants

- Apply a cover on the seedbed to reduce the amount of water

- Avoid growing tomatoes near the potato crop

- Increase ventilation by riveting and removing affected leaves.

\section{Fusarium wilt (Fusarium oxysporum) [24]}

From bottom to top, the leaves withered, turned yellow and curled at the edges. If the stem or root is cut, brown spots can be seen. Plants may only wither on one side or on the leaves, while the other half or other parts of the plant remain healthy for long periods of time. Pink fungus fluff was found in the dead plant part. Measures that can help control blight.

- Use resistant or tolerant varieties

- Take a rotation

- Remove and incinerate the affected plants

- Minimize the watering schedule. To prevent soil drying, a cover is applied to the seedbed

- Apply calcium or mud ash to reduce soil acidity

\section{Other causes of crop damage}

The abnormalities described below are not caused by insects or diseases but mostly by nutritional deficiencies and unfavourable climatic conditions.

\section{Fruit split [25]}

Very few lobes appear in the (usually mature) tomato fruit due to large fluctuations in soil water content or due to large temperature fluctuations. These reduce the quality of the fruit. The sensitivity to these fluctuations depends on the species. In addition, these divisions make it easy for pests and diseases to enter the tomato. Two ways to prevent splitting are to cover the ground with a layer of cover and gently water it but water it more often, or pick the fruit before ripening and ripen it in a dry place (for example on straw). 
Seedling and Germination Stages of Tomatoes (Solanum.lycopersicum) in Pakistan under Home Remedies, Packing and Transported to Other Countries with the Proper Identification of Pest and Diseases

\section{Sunburn (or tanning) [26]}

Brown or gray indentations appear on the fruit. The portion of the fruit that is most exposed to the sun first rots. This can be prevented by planting trees or by providing more shade during fruit ripening through sensible intercropping. Tanning tomatoes are more common.

\section{Flowering rot [27]}

This disease is caused by calcium deficiency. This is usually caused by too much salt in the soil due to the use of salt water or irrigation with too little water during the dry season. By using one or more large amounts of salt-free irrigation water (usually during the rainy season) to flush out the salt from the soil, the salt content in the soil can be reduced to ensure good drainage.

\section{Conclusion}

Tomatoes producing countries

Globally, the annual production of fresh tomatoes is about 100 million tons. However, more than a quarter of the 100 million tons are grown for the processing industry, making tomatoes the world's leading processed vegetables. The eight largest producing countries account for $84 \%$ of the world's annual production. 12) The average figures for these countries between 2003 and 2011 are as follows:

- USA (California) (9.343 million metric tonnes) $9 \%$

- Italy (4.57 million tonnes) $4 \%$

- China (3.74 million tonnes) $28 \%$

- $\quad$ Spain (3.52 million tonnes) 3\%

- Turkey (2.5 million tonnes) $7 \%$

- Brazil (1.7 million tonnes) 2\%,

- $\quad$ Greece (1.1 million tonnes)

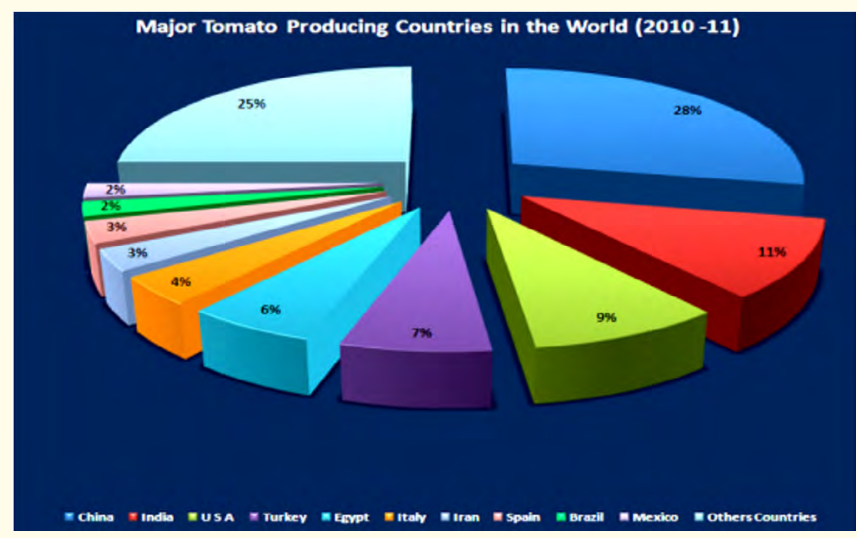

Figure 3

\section{Exporting tomatoes from Pakistan}

Tomato is a vegetable crop of great economic value in Pakistan. In general, the average annual export volume of tomatoes in the country has been about 9832 tons in the past five years. Table 4 shows the annual export volume. The lowest export figures for
2006/07 and 2007/08 are due to poor crop yields, resulting in uneconomical exports. The amount of tomatoes exported to Pakistan is 5,692 tons, and the price of tomato for $2009-10$ is 75 million rupees.

Country-wise export of tomatoes from Pakistan

\begin{tabular}{|l|c|c|c|}
\hline \multicolumn{1}{|c|}{ Year } & $\begin{array}{c}\text { Quantity } \\
\text { (tons) }\end{array}$ & $\begin{array}{c}\text { Value } \\
\text { (Million, Rs) }\end{array}$ & $\begin{array}{c}\text { Price per kg } \\
\text { (Rs) }\end{array}$ \\
\hline $2005 / 2006$ & 1030 & 10.2 & 9.4 \\
\hline $2006 / 2007$ & 515 & 4.7 & 11.9 \\
\hline $2007 / 2008$ & 977 & 11.5 & 10.5 \\
\hline $2008 / 2009$ & 4107 & 322.7 & 11.1 \\
\hline $2009 / 2010$ & 5522 & 69.9 & 11.5 \\
\hline $\begin{array}{l}\text { Average } \\
(2005-2010)\end{array}$ & 2430 & 83.3 & 10.88 \\
\hline
\end{tabular}

Table 4: Export of tomatoes from Pakistan, 2005/10 [13].

Source: Agricultural Statistics of Pakistan, Ministry of Food, Agriculture and Livestock, Government of Pakistan, Islamabad.

\begin{tabular}{|l|c|c|c|c|c|c|}
\hline Country & $\begin{array}{c}\mathbf{2 0 0 5} \\
\mathbf{- 0 6} \\
\text { (tons) }\end{array}$ & $\begin{array}{c}\mathbf{2 0 0 6} \\
\mathbf{- 0 7} \\
\text { (tons) }\end{array}$ & $\begin{array}{c}\mathbf{2 0 0 7} \\
\mathbf{- 0 8} \\
\text { (tons) }\end{array}$ & $\begin{array}{c}\mathbf{2 0 0 8} \\
\mathbf{- 0 9} \\
\text { (tons) }\end{array}$ & $\begin{array}{c}\mathbf{2 0 0 9} \\
\mathbf{- 1 0} \\
\text { (tons) }\end{array}$ & $\begin{array}{l}\text { Average } \\
\text { (tons) }\end{array}$ \\
\hline $\begin{array}{l}\text { Afghani- } \\
\text { stan }\end{array}$ & 104 & 517 & 425 & 40013 & 5290 & 9270 \\
\hline Iran & 699 & - & 391 & 28 & 1 & 224 \\
\hline UAE & - & 3 & 180 & 229 & 393 & 161 \\
\hline
\end{tabular}

Table 5

The tomato crop has enormous export potential due to its demand in the international market. Tomatoes are exported to Afghanistan, Iran, U.A.E, Saudi Arabia, Sri Lanka and India. Afghanistan, Iran and the United Arab Emirates are the main markets for Pakistan's tomato exports. Pakistan has the potential to increase its share of these markets.

Trend, area, yield and output

The area, yield and average yield of Pakistani tomatoes are shown in Table 6. From 2000-01 to 2009-10, the area of tomato crops increased from 27.9 hectares to 50,000 hectares, and the output increased from 268.8 hectares to 4.768 million hectares. At present, the average annual tomato production in the country is 10.1 tons/ha, which is quite low. In order to achieve potential production, high product grades and improved production techniques must be used.

According to the average data of five years (2005-10), the tomato production in the province is shown in Table. Balochistan is the province with the highest tomato yield, with an annual output of 206,600 tons, followed by KPK and Sindh, with a yield of 153.1 respectively. And 804,000 tons, respectively. 


\begin{tabular}{|l|c|c|c|c|c|c|}
\hline Province & $\begin{array}{c}\mathbf{2 0 0 5} \\
\mathbf{- 0 6}\end{array}$ & $\begin{array}{c}\mathbf{2 0 0 6} \\
\mathbf{- 0 7}\end{array}$ & $\begin{array}{c}\mathbf{2 0 0 7} \\
\mathbf{- 0 8}\end{array}$ & $\begin{array}{c}\mathbf{2 0 0 8} \\
\mathbf{- 0 9}\end{array}$ & $\begin{array}{c}\mathbf{2 0 0 9} \\
\mathbf{- 1 0}\end{array}$ & Average \\
\hline Punjab & 5.2 & 4.9 & 5.3 & 6.6 & 6.2 & 28.2 \\
\hline KPK & 15.2 & 15.9 & 15.2 & 14.5 & 12.5 & 73.3 \\
\hline Sindh & 10.4 & 8.9 & 11.9 & 12.4 & 13.0 & 11.32 \\
\hline Balochistan & 13.4 & 18.0 & 21.5 & 17.0 & 18.6 & 17.7 \\
\hline
\end{tabular}

Table 6

\section{Production area}

Tomatoes are grown in some parts of the county most of the year. However, during the summer and monsoon rains from June to August, the supply has decreased significantly. During the hot season, production shifts from lowlands to relatively cool and dry highlands. Due to the limited area of high yield, the supply of tomatoes has decreased during the rainy season, causing prices to rise sharply. Another stress period is the frost when production is suppressed in December and January. Pakistani tomato main growing area major growing areas of tomato in Pakistan.

\begin{tabular}{|l|l|}
\hline \multicolumn{1}{|c|}{ Zones } & \multicolumn{1}{|c|}{$\begin{array}{c}\text { Agro-ecological zones/divi- } \\
\text { sions }\end{array}$} \\
\hline Southern Punjab & $\begin{array}{l}\text { Rahim Yar Khan, Khanewal, Mu- } \\
\text { zaffargarh, Bahawalnagar, Baha- } \\
\text { walpur }\end{array}$ \\
\hline Central Punjab & $\begin{array}{l}\text { Khushab, Okara, Sahiwal, Sheikh- } \\
\text { upura, Faisalabad, Sargodha }\end{array}$ \\
\hline Northern Punjab & Gujranwala, Sialkot, \\
\hline Southern Region of Sindh & Hyderabad, Badin, Thatta, Karachi \\
\hline Northern Region of Sindh & $\begin{array}{l}\text { Mirpurkhas, Nawabshah, Now- } \\
\text { shero Feroz, Larkana Sakkur }\end{array}$ \\
\hline Uplands and Plains of KPK & $\begin{array}{l}\text { Swat, Malakand, North Waziristan, } \\
\text { Kurram }\end{array}$ \\
\hline Foothills and Plains of KPK & $\begin{array}{l}\text { Charsadda, Mardan, Swabi, Now- } \\
\text { shera }\end{array}$ \\
\hline Southern Parts of KPK & Tank, South Waziristan \\
\hline Uplands of Balochistan & Pislin, Khuzdar, Loralai \\
\hline $\begin{array}{l}\text { Plains and Foothills of } \\
\text { Balochistan }\end{array}$ & Awaran, Killa Saifulla \\
\hline
\end{tabular}

Table 7

\section{Variety}

All cultivars grown commercially in the country are imported from other countries, mainly from Europe and the United States. The main cultivar planted is; the earner, the Roman, Rio Grande.

\section{Growing season}

- Provincial seedlings planting, transplanting and harvesting tomatoes

- Province-wise nursery sowing, transplanting and harvesting times of tomatoes

\begin{tabular}{|c|c|c|c|}
\hline Province & Nursery Sowing & Transplanting & Harvesting \\
\hline Punjab & $\begin{array}{l}\text { (i) July/August } \\
\text { (Katha Saghral) } \\
\text { (ii) October } \\
\text { (Central Plains) } \\
\text { (iii) November } \\
\text { to December } \\
\text { March/April } \\
\text { (Hilly Areas) }\end{array}$ & $\begin{array}{l}\text { (i) August/ } \\
\text { September } \\
\text { (ii) November } \\
\text { (iii) February/ } \\
\text { March } \\
\text { May/ } \\
\text { June }\end{array}$ & $\begin{array}{l}\text { (i) December } \\
\text { to February } \\
\text { (ii) April to } \\
\text { May } \\
\text { (iii) May to } \\
\text { June } \\
\text { August to } \\
\text { October }\end{array}$ \\
\hline КРК & $\begin{array}{l}\text { (i)August (Dargai) } \\
\text { (ii) April to May } \\
\text { (Northern Areas) } \\
\text { (iii) May to June }\end{array}$ & $\begin{array}{l}\text { (i) October } \\
\text { (ii) May to June } \\
\text { (iii) June to July }\end{array}$ & $\begin{array}{l}\text { (i) December } \\
\text { to January } \\
\text { (ii) July to } \\
\text { August } \\
\text { (iii) October } \\
\text { to November }\end{array}$ \\
\hline Sindh & $\begin{array}{l}\text { (i) June/July } \\
\text { (ii) August to } \\
\text { October } \\
\text { (iii) December }\end{array}$ & $\begin{array}{l}\text { (i) July/August } \\
\text { (ii) September } \\
\text { to November } \\
\text { (iii) February }\end{array}$ & $\begin{array}{l}\text { (i) September } \\
\text { to November } \\
\text { (ii) December } \\
\text { to February } \\
\text { (iii) May to } \\
\text { June }\end{array}$ \\
\hline $\begin{array}{l}\text { Balo- } \\
\text { chistan }\end{array}$ & $\begin{array}{l}\text { November/ } \\
\text { December }\end{array}$ & $\begin{array}{l}\text { March/April/ } \\
\text { May }\end{array}$ & $\begin{array}{l}\text { May-June } \\
\text { June- August }\end{array}$ \\
\hline
\end{tabular}

Table 8

\section{Fertilization}

The general recommendation for the application of chemical fertilizers is $46 \mathrm{~kg}$ of nitrogen per hectare, $60 \mathrm{~kg}$ of phosphorus and $25 \mathrm{~kg}$ of potash. For better results, all phosphorus and half of the nitrogen and potassium fertilizer should be applied before transplanting the seedlings. The remaining half of the nitrogen and potassium fertilizers should be applied 6-8 weeks after transplanting.

Irrigation Tomatoes are not resistant to drought. After a short period of water shortage, production will drop significantly. It is important to water the plants on a regular basis, especially during flowering and fruiting. The amount of water required depends on the type of soil and the weather (rain, humidity and temperature). About 20 millimeters of water per week is required under cool conditions and about 70 millimeters of water is required during hot and dry periods Watering plays a major role in achieving uniform maturation and reducing the incidence of flowering rot. Flowering rot is a physiological barrier associated with irregular water supply and causes calcium deficiency in the fruit during its expansion. Plants can be irrigated after transplantation. It is recommended to irrigate between 7-8 days. When the weather is too hot, the irrigation interval can be reduced from 5-6 days. A sufficient amount of irrigation water should be given, but be careful not to allow the bed to immerse in water. 
Seedling and Germination Stages of Tomatoes (Solanum.lycopersicum) in Pakistan under Home Remedies, Packing and Transported to Other Countries with the Proper Identification of Pest and Diseases

\section{Weeding}

Weeds compete with tomato plants for light, water and nutrition. Sometimes they provide shelter for organisms that cause tomato disease, such as tomato yellow leaf curl virus (TYLCV), and reduce yield. Effective non-chemical weed management begins with deep ploughing, multiple crop rotations and competitive cover crops.

The following comprehensive practices are very useful for effective weed control:

- $\quad$ Remove previous crop residues and use hygienic practices to avoid introducing weed seeds.

- Deep ploughing and exposure to sunlight before transplanting can help destroy weed seeds.

- It is very important to keep wild weeds for 4-5 weeks after transplanting. During this time, weed competition must be suppressed to avoid a reduction in production.

- Weeds growing between crop rows are the easiest to control.

- Shallow tillage (up to $15-20 \mathrm{~cm}$ ) or the use of a cover usually removes them.

- $\quad$ The tilting of the soil to the plants (grounding) helps to kill the small weeds in the rows, and the tomato plants develop further on the stems.

- $\quad$ Covering with plant residues is conducive to weed suppression, soil moisture retention and slow release of nutrients

Harvesting of tomatoes

The harvest will last for about a month, depending on the climate, the disease and the variety planted. Tomatoes can be divided into four stages of maturity:

- $\quad$ Stage 1: Seeds are white (immature) and can be cut when sliced. There is no juice in the tomato.

- $\quad$ Stage 2: The seeds are brown (mature) and some juices are present.

- $\quad$ Stage 3: Push the seeds aside while cutting. The color inside is still green.

- $\quad$ Stage 4: The juice turns red.

Tomatoes harvested in the first stage of ripening will mature into inferior tomatoes. Tomatoes harvested in the mature third and fourth stages will mature into high quality tomatoes. Careful study of the maturity of tomatoes is also very good.

More mature Tomatoes at harvest can affect fruit composition and tomato quality. Tomatoes accumulate acid, sugar and ascorbic acid when they mature. Mature tomatoes in the field have better flavor and overall quality than mature tomatoes after harvesting. Therefore, it is important to understand the maturity stage. The simple color index of red tomatoes can be given to tomato pickers so that they are familiar with this.

\section{Post-harvest treatment}

Tomato picking picking container (nylon mesh bag or plastic bucket). These sorting containers need to be poured into larger containers that weigh no more than $25 \mathrm{~kg}$. The container only needs to contain mature, mature and undamaged tomatoes. When the field containers are full, they should be transported to the sorting area of the farm. In the sorting area, the fruits are washed and sorted by size, color and type. The sorting area needs to be protected from direct sunlight, preferably cooled and cleaned. Long water containers can be used for cleaning and sorting. It is also possible to sterilize tomatoes by adding an allowable amount of chlorine solution to the water. After the tomatoes are removed from the sorting tube, they must be dried and carefully placed in a container ready for delivery to the final destination. Unity is one of the first attributes buyers are looking for. The appearance comes from the aroma and taste.

\section{Bale/Packing}

Poorly packaged tomatoes not only destroy the sale of the tomato crop, but also mean a price cut. Even if tomatoes are only sold at the farm gate, they also need some form of packaging, which can be a simple traditional basket. Packaging prevents pathogens, natural carnivores, water loss, temperature, breakage, tomato deformation and bruises. It is a good idea to use a filler material between the bottom of the package and the tomato layer.

\section{Storage}

If not refrigerated, storing tomatoes in tropical and subtropical climates can be difficult. Freshly sold tomatoes for table consumption should not be stored for long periods of time. Tomatoes are picked at maturity, stored in a cool room for a few days, and shipped to distant markets. On the road, tomatoes will mature to the market stage. Exported tomatoes are usually shipped in large containers with refrigeration equipment and ethylene handling equipment. If the tomato is stored at a temperature below $10^{\circ} \mathrm{C}$ for more than 2 weeks, or if it is stored at $5^{\circ} \mathrm{C}$ for more than 6 to 8 days, it will deteriorate.

\section{Future strategy}

1. Tomato germplasm resistant to antiviral and high summer temperatures should be introduced for adaptation, or used in hybridization programs to develop new high-yield diseaseresistant varieties.

2. Research should be conducted to find appropriate and effective ways to combat the Oroban issue in the affected areas.

3. Protective cultivation techniques should be introduced on a large scale to supply products during scarcity.

4. Control the branches/fruit mites.

5. Use growth regulators to get better fruit.

6. Shelf life extension/post-harvest study. 


\section{Bibliography}

1. Beecher GR. "Nutrient content of tomatoes and tomato products". Proceedings of the Society for Experimental Biology and Medicine 218.2 (1998): 98-100.

2. https://draxe.com/tomato-nutrition/

3. file:///C:/Users/Umar\%20Javed/Desktop/Tomato-Production-Guideline-2014.pdf

4. Allan J A. "Policy Responses to the Closure of Water Resources: Regional and Global Issues. In: Water Policy: Allocation and Management in Practice, edited by P. Howsam and R.C. Carter (1996).

5. Oki T and S Kanae. "Virtual Water Trade and World Water Resources". Water, Science, and Technology 49.7 (2004): 203209.

6. Hartz T and B Hanson. "Drip irrigation and fertigation management of processing tomato". Vegetable Research and Information Center, University of California (2009).

7. LeBoeuf J., et al. "Irrigation Scheduling for tomatoes - an introduction. Ministry of Agriculture, Food and Rural Affairs". Ontario, Canada (2008): 08-011.

8. Hayley Boriss and Henrich Brunke. "Fresh Tomatoes Profile." Agricultural Marketing Resource Center. AgMRC (2005).

9. "State Census number of farms with tomatoes, acres harvested, and percentage irrigated, 1978, 1982, 1987, 1992, 1997, 2002, and 2007." (2014).

10. G. Hochmuth and R. Hochmuth. "Production of Greenhouse Tomatoes - Florida Greenhouse Vegetable Production Handbook, Vol 3." EDIS. University of Florida IFAS Extension (1990).

11. G. Hochmuth and R. Hochmuth. "Production of Greenhouse Tomatoes - Florida Greenhouse Vegetable Production Handbook, Vol 3." EDIS. University of Florida IFAS Extension (1990).

12. http://agriexchange.apeda.gov.in/Market\%20Profile/MOA/ Product/Tomato.pdf

13. Federal board of statistics govt of Pakistan

14. Production and pest management information; updated annually; especially useful for listings of insecticides, fungicides, and herbicides

15. Zamir D., et al. "Mapping and introgression of a Tomato Yellow Leaf Curl Virus Tolerance Gene, Ty-1". Theoretical and Applied Genetics 88 (1994): 141-146.
16. Scott J W and John Paul Jones. "Fla. 7775 and Fla. 7781: Tomato breeding lines Resistant to Fusarium Crown and Root Rot" HortScience: a publication of the American Society for Horticultural Science 35.6 (2000): 1183-1184.

17. Khajuria Shakti., et al. "Response of aphid, Myzus persicae (Sulzer) to tomato varieties". Journal of Experimental Zoology, India 11.2 (2008): 449-450.

18. Oscar J P M., et al. "Effects of temperature on the life history of Liriomyza trifolii on tomato". Journal of Economic Entomology 33.1 (1999): 117-125.

19. Tarsem Singh Dhillon. "Package of practices for cultivation of vegetables". Punjab Agricultural University, Ludhiana, Punjab, India (2015).

20. Kiranmai G., et al. "Molecular cloning and detection of cucumber mosaic cucumovirus causing infectious chlorosis of banana using DNA probes". Indian Phytopath. Soc. Golden Jublee Int. Conf. (1997): 10-15.

21. Polston J E. "Tomato yellow leaf curl virus Revisted". In Proc.of the Florida Tomato Institute PRO520 (2003): 9-11.

22. Jones J P., et al. "Compendium of Tomato Diseases". American Phytopathological Society, St. Paul, MN (1991): 13-14.

23. Stevenson W R., et al. "Compendium of tomato diseases. American Phytopathological Society Press, St. Paul, MN (1991): 1314.

24. Haridon F., et al. "Isolation of differentially expressed genes during interactions between tomato cells and a protective or a non-protective strain of Fusarium oxysporum". Physiological and Molecular Plant Pathology 76.1 (2011): 9-19

25. Cuartero J., et al. "Tomato fruit cracking under plastic-house and in the open air. II. General and specific combining abilities". Genetics and Breeding of Tomato. Avignon, France (1981): 91-98.

26. Hartati YS. “Optimization of sorbitol, glycerol, and propylenegl ycol mixture in sunscreen gel of ethanolic extract of Curcuma manga". Majalah Farmasi Indones 21 (2010): 83-89.

27. Blossom End Rot of Tomatoes and Other Vegetables. Martin A. Draper, Rhoda Burrows, and Steven Munk. South Dakota Extension Fact Sheet 909 (2002).

\section{Volume 3 Issue 9 September 2019 (C) All rights are reserved by Faryal Fatima and Muhammad Umar Javed}

